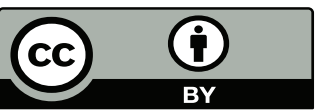

\title{
Perinteinen ja paikallinen tieto maankäytön suunnittelussa - esimerkkinä Enontekiö
}

\begin{abstract}
Traditional and local knowledge in land use planning - Enontekiö as an example Land Use and Building Act provides interaction and participation of local people in land use planning. Convention on Biological Diversity requires traditional and local knowledge to be taken into account in land use planning. In the Saami homeland of Finland Metsähallitus, first in the world, has applied the voluntary Akwé: Kon Guidelines to fulfill the requirements of the Convention. Here we study the experiences of applying Akwé: Kon Guidelines into land use planning, based on PPGIS (Public Participatory GIS) survey and interviews of officials and local Saami reindeer herders conducted in 2016-2018 in Enontekiö. The Saami informants reported that Reindeer Husbandry Act does not recognize and protect the Saami reindeer herding system and related knowledge, and this makes inclusion of traditional knowledge into land use planning very difficult. The planners of Metsähallitus brought out the need for exact localization of knowledge and problems related to the inclusion of experience-based knowledge into planning systems. Participatory GIS methods may offer a functional tool for documenting traditional knowledge, but unsolved questions related to the access to natural resources and Saami cultural heritage make knowledge localization on the maps challenging.
\end{abstract}

Keywords: Akwé: Kon Guidelines, land use planning, local knowledge, traditional knowledge, Saami Homeland

\section{Johdanto}

Yhdyskuntasuunnittelussa erilaisten näkökantojen huomioiminen ja yhteensovittaminen on keskeistä kestävän lopputuloksen saavuttamiseksi. Maankäyttö- ja rakennuslaki (132/1999) edellyttää vuorovaikutteisuutta maankäytön suunnittelussa. Jokaisella, jota kaavoitus tai muu maankäytön suunnitelma koskee, on oikeus osallistua suunnitteluun ja ilmaista asiasta mielipiteensä. Kokemusperäisen paikallistiedon tuominen osaksi suunnitteluprosesseja on hyvä keino edistää vuorovaikutteisuutta. Paikallisen kokemustiedon käyttö osana maankäytön

\footnotetext{
a Arktinen keskus, Lapin yliopisto, inkerimarkkula2@gmail.com

b Arktinen keskus, Lapin yliopisto, minna.turunen@ulapland.fi

c Luonnonvarakeskus, seija.tuulentie@luke.fi

d Luonnonvarakeskus, ari.nikula@luke.fi
} 
suunnitteluprosesseja edesauttaa ekosysteemien, luonnonvarojen ja biodiversiteetin suojelua ja tuo esiin paikallisten asukkaiden tarpeita, huolia ja toiveita (Yli-Pelkonen \& Kohl 2005; Forbes ym. 2006; Alessa ym. 2008; Berkes 2012; Danielsen ym. 2009, 2014).

Perinteinen tieto on kokemusperäisen paikallistiedon osa-alue, joka on luonteeltaan yhteisöllistä, sukupolvelta toiselle kulttuurisen siirron kautta kulkevaa tietoa, jonka keskiössä on ihmisen ja ympäröivän luonnon suhde (Berkes 1993). Biologista monimuotoisuutta koskevan yleissopimuksen (Biodiversiteettisopimus, CBD 1992) artikla 8(j) velvoittaa sopimusosapuolia kunnioittamaan, suojelemaan ja ylläpitämään alkuperäiskansojen ja paikallisten yhteisöjen sellaista tietämystä, keksintöjä ja käytäntöä, joka sisältyy biologisen monimuotoisuuden suojelun ja kestävän käytön kannalta merkityksellisiin perinteisiin elämänmuotoihin ja edistää ja laajentaa niiden soveltamista mainittujen yhteisöjen luvalla. Suomessa CBD:n artiklan 8(j) velvoitteiden katsotaan koskevan erityisesti saamelaisalueen maankäytön suunnittelua. Saamelainen perinteinen tieto on sidoksissa kieleen, alueeseen ja elinkeinoihin, kuten poronhoitoon, jonka harjoittamisessa perinteisellä tiedolla on edelleen suuri merkitys (Markkula \& Helander 2014; Olsén ym. 2017). Niin perinteinen tieto kuin biodiversiteettisopimuksen velvoitteetkin liittyvät kiinteästi ajatukseen biokulttuurisesta monimuotoisuudesta. Biokulttuurinen monimuotoisuus on käsite, joka yhdistää biologisen monimuotoisuuden ihmisten kulttuurin ja kielten rikkauteen (Chen \& Gilmore 2015). Biokulttuurinen monimuotoisuus kattaa siis käytännössä kaikki alueisiin liittyvät kulttuuriset ja biologiset arvot eliölajeista pyhiin paikkoihin. Biokulttuurisista oikeuksista puhutaan taas silloin, kun halutaan painottaa alkuperäiskansojen oikeutta kulttuuriin, perinteeseen, elinympäristöön ja luonnonvarojen kestävään hallintaan. Biodiversiteettisopimus on yksi näitä oikeuksia suojaavista sopimuksista.

Artiklan 8(j) velvoitteiden täyttämiseksi Metsähallitus on ottanut käyttöön vapaaehtoiset biodiversiteettisopimuksen sihteeristön tuottamat Akwé: Kon -ohjeet (Ympäristöministeriö 2011). Ohjeet ovat nykyään Metsähallituksen vakituinen työkalu maankäytön suunnittelussa saamelaisalueella, ja ne on tarkoitettu käytettäväksi

"sellaisten hankekeiden ja suunnitelmien kulttuuri-, ympäristö- ja sosiaalisten vaikutusten arvioinnissa, jotka voivat vaikuttaa saamelaiskulttuurïn, -elinkeinoibin ja kulttuuriperintöön. Objeiden tarkoitus on turvata luonnon monimuotoisuuden säilyminen sekä alkuperäiskansakulttuurin luontosubteen ja perinteisen tiedon säilyminen.” (Ympäristöministeriö 2011)

Akwé: Kon -ohjeet tarjoavat menettelytavan, jolla turvataan saamelaisten osallistuminen erilaisten hankkeiden ja suunnitelmien valmisteluun, vaikutusten arviointiin ja päätöksentekoon.

Saamelaiset ja muut alkuperäiskansat ovat tuoneet ilmi, että heidän perinnetietojaan ei tulisi vain käyttää hyväksi maankäytön suunnittelussa ja tutkimushankkeissa, vaan tiedon keruun ja tutkimuksen tulisi tapahtua yhteistyössä. Kun alkuperäiskansat tuottavat, käsittelevät ja jakavat tietoa yhteistyössä tutkijoiden tai maankäytön suunnittelijoiden kanssa, lopputulos vastaa paremmin heidän todellisuuttaan ja arvojaan kuin silloin, jos tutkijat ja suunnittelijat keräävät ja analysoivat tiedon (esim. Berkes 2009; Armitage ym. 2011; Olsén 2017). Akwé: Kon -ohjeiden käyttöönotto voidaan osaltaan nähdä vastauksena näihin vaatimuksiin.

Osallistavat paikkatietomenetelmät Public Participatory Geographical Information System (PPGIS) ja Participatory Geographical Information System (PGIS) ovat keskeisiä työkaluja kokemusperäisen tiedon paikallistamisessa, ja niitä on käytetty monin eri tavoin maankäytön suunnittelussa (Brown \& Kyttä 2014). Asuinalueeseen ja ympäristöön liittyvä tieto on usein paikkasidonnaista, ja sitä on luontevaa kerätä ja esittää karttapohjaisten sovellusten avulla. Osallistavien paikkatietojärjestelmien avulla kerätään paikkoihin liittyviä ominaisuustietoa, esimerkiksi arvoja, maankäytön ristiriitoja, alueisiin liittyviä toiveita ja muutostarpeita (esim. 
Alessa ym. 2008; Brown \& Kyttä 2014; Kivinen ym. 2018). Käyttäjä voi merkitä tiedon kartalle pisteenä, viivana (esim. reitti) tai alueena.

Suomessa osallistavia paikkatietomenetelmiä on käytetty $\mathrm{mm}$. kaupunkisuunnittelussa (Kahila \& Kyttä 2009; Brown \& Kyttä 2014; Kahila-Tani ym. 2016), matkailututkimuksessa (Tolvanen ym. 2014; Kantola ym. 2018), kaivosalueisiin liittyvässä tutkimuksessa (Kivinen ym. 2018) sekä valtion metsien käytön suunnittelussa (Heikkonen 2014; Pietilä \& Fagerholm 2018). Karttapohjaisten sovellusten käyttöön alkuperäiskansojen asuttamilla alueilla, kuten saamelaisalueella, liittyy kuitenkin edelleen avoimia kysymyksiä, joista on Suomessa varsin vähän keskusteltu (ks. esim. Barlindhaug 2013; Veland ym. 2014; Gadamus \& RaymondYakubian 2015). Nämä kysymykset liittyvät saamelaiseen kulttuuriperintöön ja tiedon hallintaan: kenellä on oikeus kerätä yhteisölle kuuluvaa perinteistä tietoa ja minkälaisiin tarkoituksiin tätä tietoa voidaan käyttää?

Tarkastelemme tässä tutkimuksessa paikallisen ja perinteisen tiedon sisällyttämistä maankäytön suunnitteluun ja selvitämme siihen liittyviä haasteita, menetelmiä ja avoimia kysymyksiä. Tutkimus pohjautuu haastatteluihin sekä osallistavaan paikkatietokyselyyn, jotka toteutettiin Enontekiön kunnassa vuosina 2016-2018. Tarkastelemme Enontekiön tapaustutkimuksen avulla erityisesti: 1) haasteita, jotka liittyvät kokemusperäisen paikallisen ja perinteisen tiedon sisällyttämiseen maankäytön suunnitteluun, 2) Akwé: Kon -ohjeiden soveltamiseen liittyviä kokemuksia eli sitä, onko ohjeiden käyttöönotto vaikuttanut perinteisen tiedon asemaan maankäytössä saamelaisalueella, sekä 3) erityiskysymyksiä, jotka liittyvät osallistavien paikkatietomenetelmien käyttöön saamelaisalueella.

\section{Akwé: Kon -ohjeiden soveltaminen Suomen saamelaisalueella}

Ympäristöministeriö nimitti vuonna 2009 CBD:n artiklan 8(j) kansallisen asiantuntijaryhmän, jonka tehtävänä oli koordinoida Suomen luonnon monimuotoisuuden suojelun ja kestävän käytön strategian ja toimintaohjelman 2006-2016 tarkoittamia alkuperäiskansojen perinnetietoa koskevia toimenpiteitä. Asiantuntijatyöryhmän tehtävinä oli myös edistää työohjelman toimeenpanoa yhteistyössä eri ministeriöiden ja sidosryhmien kanssa sekä antaa suosituksia siitä, miten sopimusta voitaisiin toteuttaa (Ympäristöministeriö 2011). Työryhmä esitti loppuraportissaan, että kaikessa saamelaisten kotiseutualueen maankäytön suunnittelussa ja ohjauksessa sovellettaisiin biodiversiteettisopimuksen alaisia Akwé: Kon -ohjeita kansallisen lainsäädännön puitteissa (Juntunen \& Stolt 2013). Vuonna 2010 Metsähallitus ja saamelaiskäräjät aloittivat valmistelut ohjeiden soveltamiseksi ja niitä testattiin Inarin kunnassa sijaitsevan Hammastunturin erämaan hoito- ja käyttösuunnitelman päivityksen yhteydessä ensimmäistä kertaa maailmassa (Juntunen \& Stolt 2013; Metsähallitus 2016).

Akwé: Kon -ohjeiden mukaisesti alkuperäiskansan edustajilla on mahdollisuus osallistua kaikkiin maankäytön vaiheisiin, suunnittelusta toteutukseen ja seurantaan (Juntunen \& Stolt 2013; Metsähallitus 2016). Tämä on ohjeiden soveltamisen mukanaan tuomista parannuksista tärkein, sillä aiemmin saamelaiskäräjät arvioi maankäytön ja hallinnan suunnitelmien vaikutukset vasta suunnitelmien valmistuttua (Juntunen \& Stolt 2013). Akwé: Kon -ohjeita sovellettaessa saamelaisedustajat osallistuvat alusta lähtien maankäytön suunnittelun prosessiin ja vaikutusten arviointi on jatkuvaa. Käytännössä suunnitteluprosessin alussa saamelaiskäräjät nimittää Akwé: Kon -työryhmän. Työryhmän jäsenet (tavallisesti viisi jäsentä) ovat suunnittelun alaisen alueen käyttäjiä ja perinteisen tiedon haltijoita, ja ohjeiden periaatteiden mukaisesti heidän tulisi edustaa eri ikäisiä ja eri kieliryhmiin kuuluvia sekä eri sukupuolta olevia saamelaisia. Valtio rahoittaa työryhmien työn saamelaiskäräjille ja Metsähallitukselle myönnettävien resurssien kautta. 


\section{Aineisto ja menetelmät}

\section{Tutkimusalue}

Enontekiö on 1900 asukkaan kunta saamelaisalueella, joka rajautuu suureksi osaksi Norjaan ja Ruotsiin. Kunnan pinta-ala on 856400 hehtaaria, ja suurin osa kunnan maa-alasta on valtion omistuksessa. Luonnonsuojelualueet, kuten Mallan luonnonpuisto, erämaa-alueet (Käsivarsi, Pöyrisjärvi, Tarvantovaara ja Pulju), Saanan suojelualue, Pallas-Yllästunturin kansallispuisto ja useat pienemmät suojelualueet, kattavat yli 65 prosenttia kunnan maaalasta (kuva 1). Poronhoito on sallittua erämaa-alueilla ja kansallispuistoissa. Vuonna 1991 perustettujen erämaa-alueiden tavoitteena on alueiden erämaaluonteen säilyttäminen, saamelaiskulttuurin ja luontaiselinkeinojen turvaaminen sekä luonnon monipuolisen käytön ja sen edellytysten kehittäminen (Erämaalaki 1991/62).

Metsähallituksen hallinnoimien erämaa-alueiden suojelu ja hoito perustuu alueiden hoito- ja käyttösuunnitelmiin. Hoito- ja käyttösuunnitelmien avulla sovitetaan yhteen luonnonsuojelun, virkistyskäytön ja muun käytön tavoitteita aina 10-15 vuoden ajanjaksolle. Suunnitelmissa analysoidaan perustietojen pohjalta alueen nykytila, tärkeimmät arvot, tuleva kehitys ja uhkatekijät sekä hoidon ja käytön tavoitteet. Yleisöllä

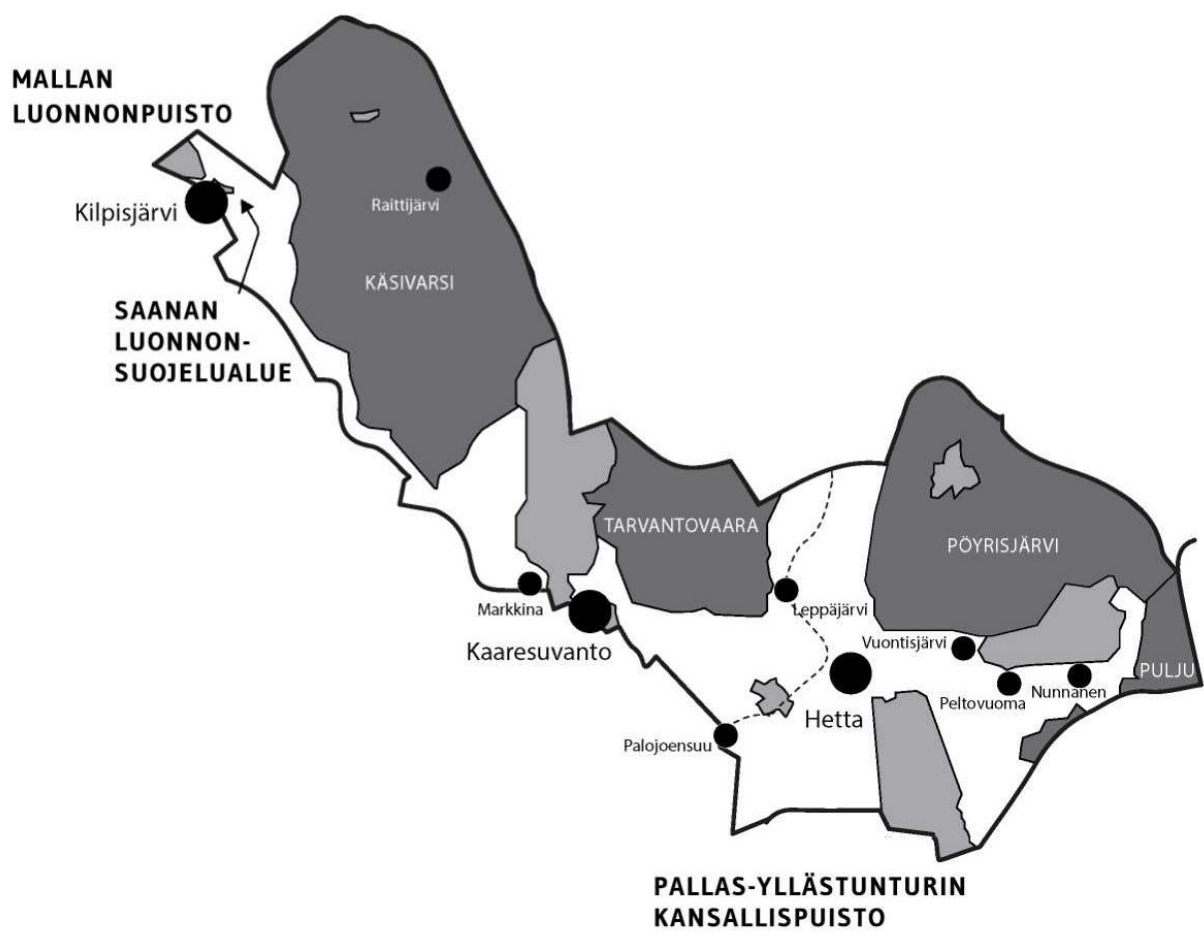

Kuva I.Tutkimusalue ja luonnonsuojelualueet Enontekiön kunnassa. Käsivarren erämaa-alue on pinta-alaltaan 264950 hehtaaria, Saanan luonnonsuojelualue 12297 hehtaaria. Puljun erämaa-alue on 69206 hehtaaria, josta 30 \% sijaitsee Enontekiön alueella. Käsivarsi ja Saana ovat Käsivarren paliskunnan laidunalueita. Puljun erämaaalue on Näkkälän paliskunnan talvilaidunalue.

Figure I. Research area and wilderness and conservation areas of Enontekiö. The Käsivarsi Wilderness Area consists of 264950 hectares, and the Saana Area 12297 hectares. The Pulju Wilderness Area is 69206 hectares in area, of which $30 \%$ is located in the municipality of Enontekiö. Käsivarsi and Saana are pasture areas for the Käsivarsi reindeer herding cooperative.The Pulju Wilderness Area serves as winter pastureland for the Näkkälä reindeer herding cooperative. 
ja sidosryhmillä on mahdollisuus tuoda näkemyksiään esiin ja vaikuttaa suunnitelmiin koko suunnitteluprosessin ajan. Metsähallitus soveltaa Akwé: Kon -ohjeita kaikessa maankäytön suunnittelussa saamelaisalueella.

Enontekiöllä on kaksi paliskuntaa, Käsivarsi ja Näkkälä. Paliskuntain yhdistyksen (2018) mukaan Käsivarren paliskunnan suurin sallittu poromäärä on 10000 ja Näkkälän paliskunnan 8300 poroa. Enontekiön kunnassa on 365 poronomistajaa. Alueen saamelaisporonhoito perustuu siida-järjestelmään, joka on perinteinen saamelainen sosioekonominen instituutio (Lehtola 2004). Siida tarkoittaa sukuun perustuvaa kyläryhmää. Siidat eli lapinkylät ovat saamelaisten yhteisöjä, joiden jäsenillä on yhteiset elinkeinot ja nautinta-alueet.

Enontekiö valikoitui tutkimusalueeksi, koska alueella on monenlaista maankäyttöä sekä erilaisia ongelmatilanteita ja kiistoja liittyen muun muassa matkailuun, poronhoitoon ja luonnonsuojeluun (esim. Jokinen ym. 2016; Tuulentie 2017). Tämän lisäksi kunnan sijainti Ruotsin ja Norjan rajanaapurina antaa mahdollisuuden tutkia rajat ylittävää maankäyttöä. Akwé: Kon -ohjeistusta on Enontekiöllä käytetty hiljattain Saanan alueen sekä Käsivarren ja Puljun erämaa-alueiden hoito- ja käyttösuunnitelmien yhteydessä (Metsähallitus 2017a, 2017b, 2018). Metsähallituksen lisäksi Enontekiön kunta on ensimmäisenä kuntana maailmassa soveltanut Akwé: Kon -ohjeita tuulivoimarakentamista ohjaavan yleiskaavan suunnittelutyössä.

\section{Haastattelut ja osallistava paikkatietokysely}

Tutkimuksen aineisto koostuu haastatteluista ja paikkatietokyselystä. Paikkatietokyselyn tavoitteena oli tavoittaa mahdollisimman laajasti alueen eri käyttäjäryhmiä (esim. poronhoitajat, muut paikalliset ihmiset, matkailijat, matkailuyrittäjät) ja kartoittaa heille tärkeitä arvoja ja alueita. Henkilökohtaisten haastattelujen tavoitteena oli selvittää tarkemmin Akwé:Kon -ohjeiden kohderyhmänä olevien saamelaisten näkemyksiä kokemusperäisen paikallistiedon ja perinteisen tiedon sisällyttämisestä maankäytön suunnitteluun tutkimusalueella sekä tuoda esiin maankäytön suunnittelun parissa työskentelevien virkamiesten näkemyksiä ja kokemuksia.

Haastattelimme Enontekiöllä seitsemää maankäytön suunnittelusta vastaavaa virkamiestä ja kuutta paikallista saamelaista poronhoitajaa Näkkälän ja Käsivarren paliskunnista lokakuun 2016 ja marraskuun 2017 välillä. Kaksi haastatelluista virkamiehistä työskenteli Enontekiön kunnan teknisellä osastolla ja viisi työskenteli Metsähallituksessa. Haastateltavien työkokemus vaihteli 7-27 vuoden välillä. Saamelaisilla informanteilla oli 2-30 vuoden kokemus osallistumisesta maankäytön suunnitteluprosesseihin ja neuvotteluihin. Haastateltavat olivat 32-60-vuotiaita: yhdeksän miestä ja neljä naista. Heitä tiedotettiin Lapin yliopiston tutkimuseettisten ohjeiden (2009) mukaisesti tutkimuksen tavoitteesta ja siitä, mihin tarkoitukseen haastatteluja käytetään. Kaikki haastateltavat antoivat suostumuksensa tutkimukseen.

Haastattelut tehtiin suomeksi, nauhoitettiin ja litteroitiin. Tekstissä on esitetty lainauksia litteroiduista haastatteluista. Haastatellut henkilöt on koodattu numeroilla 1-13, joiden perässä on heidän työpaikkaansa kuvaava lyhenne PPY (paikallinen poronhoitoyhteisö), MH (Metsähallitus) tai EK (Enontekiön kunta).

Haastattelut olivat avoimia teemahaastatteluja, joissa informantteja pyydettiin arvioimaan seuraavia asioita: Millaista tietoa maankäytön suunnittelun tueksi kerätään? Millainen tieto maankäytön suunnittelussa on tärkeintä ja millä tiedolla on eniten vaikutusta päätöksiin? Onko jotakin tietoa, jota ei huomioida lainkaan maankäytön suunnittelussa tai jota tulisi kerätä enemmän? Onko paikallisten ihmisten kuulemisessa ja paikallisen/perinteisen tiedon hyödyntämisessä tapahtunut muutoksia oman työurasi aikana tai sinä aikana, kun olet ottanut osaa maankäytön suunnitteluun? Jos on, mikä on vaikuttanut tähän? Mikä on lainsäädännön, biodiversiteettisopimuksen ja Akwé: Kon -ohjeiden merkitys mahdollisissa muutoksissa? Mitä haittaa ja hyötyä paikallisen/perinteisen tiedon käytössä osana maankäytön suunnittelua on tai voi olla? 
Haastattelut analysoitiin kvalitatiivisen sisällönanalyysin avulla (Tuomi \& Sarajärvi 2009). Haastattelujen analysoinnissa keskityimme kolmeen ennalta määriteltyyn teemaan: 1) Akwé: Kon -ohjeiden merkitys ja suunnittelussa tapahtuneet muutokset, erityisesti perinteisen tiedon näkökulmasta, 2) kokemusperäisen paikallisen ja perinteisen tiedon sisällyttämiseen liittyvät haasteet, sekä 3) tiedon kartoitus ja dokumentointi.

Haastatteluja täydentävänä kirjallisena materiaalina käytimme kolmea Metsähallituksen hoito- ja käyttösuunnitelmaa (Käsivarren ja Puljun erämaa-alueet ja Saanan alue), joiden laatimisessa on noudatettu Akwé: Kon -menettelytapaa (Metsähallitus 2017a, 2017b, 2018).

Osallistava paikkatietokysely tehtiin osana Luonnonvarakeskuksen johtamaa Building Shared Knowledge Capital to Support Natural Resource Governance in the Northern Periphery (BuSK) -projektia, joka toteutettiin vuosina 2016-2019 (ks. http://busk. interreg-npa.eu/). Projektin tavoitteina oli kartoittaa kansalaisten näkemyksiä ympäristöstä ja maankäytöstä, tehdä kansalaistietoa havainnollisemmaksi ja täsmällisemmäksi uusien menetelmien avulla sekä parantaa päätöksentekoa maankäytön suunnittelussa. Paikkatietokysely toteutettiin Harava-karttakyselypalvelua käyttäen. Luonnonvarakeskus pyysi saamelaiskäräjiltä kommentteja sekä lausunnon karttakyselyyn vuonna 2016 käyttöönotetun tutkimuseettisen menettelyohjeen (ks. https://www.samediggi.fi/ tutkimuseettinen-menettelyohje) mukaisesti.

Kysely oli avoinna internetissä 20.2.-31.8.2018 välisen ajan. Vastaajia pyydettiin antamaan taustatietoina ikä, syntymä- ja asuinpaikka, sukupuoli ja ammatti. Kyselyä mainostettiin muun muassa sosiaalisessa mediassa ja Enontekiön alueen paikallislehdessä.

Vastaajia pyydettiin merkitsemään kartalle tärkeitä paikkoja ja tämän jälkeen kuvaamaan, miksi paikka on tärkeä. Vastaaja pystyi valitsemaan paikkaa kuvaavista maisema-arvoista yhden tai useamman sekä lisäksi kuvaamaan paikkaa avoimessa vastauksessa. Maisemaarvoja olivat: hiljaisuus, erityinen luonnonarvo, luonnon monimuotoisuus, metsästys, kalastus ja keräily, poronhoito, puhdas vesi, kulttuuriperintö, historiallinen paikka, pyhä/ uskonnollinen paikka, virkistys, kaunis maisema, terveys ja hyvinvointi, tärkeys tuleville sukupolville, mahdollisuus oppimiseen, paikan esittely vierailijoille/turisteille, ihmisten kohtauspaikka ja itsessään arvokas paikka. Maisema-arvot valittiin tutkimuskirjallisuuteen perustuen (Alessa ym. 2008). Vastaajia pyydettiin merkitsemään kartalle myös paikkoja, joihin liittyy maankäytön ristiriitoja. Tässä artikkelissa keskitymme tarkastelemaan paikkatietomenetelmien hyötyjä ja haasteita erityisesti perinteisen tiedon tallentamisessa ja sen tuomisessa osaksi päätöksentekoa Enontekiön kunnan alueelle rajatun tapaustutkimuksemme kautta sekä pohdimme vastausten edustavuutta.

\section{Tulokset}

\section{Haastateltavien kokemukset Akwé: Kon -menettelytavasta}

Haastateltavien näkemykset Akwé: Kon -menettelytavan käytöstä ja niiden mukanaan tuomista muutoksista maankäytön suunnittelussa erosivat toisistaan jonkin verran. Osan mielestä ohjeet ovat tärkeä ja käyttökelpoinen suunnittelun väline, joka tuo suunnitteluun aivan uuden elementin (3, MH; 12,13, PPY), kun taas toiset olivat sitä mieltä, että haastatteluiden ajankohtana oli vielä liian aikaista arvioida suhteellisen uuden menettelytavan vaikutuksia (4, MH; 5, 6, EK; 7, PPY). Erään informantin mukaan Akwé: Kon -menettelytapa on parantanut hoito- ja käyttösuunnitelmien tietopohjaa ja tiedonkeruuprosessia, sillä ohjeiden käyttöönoton jälkeen paikallisista saamelaisista koostuva Akwé: Kon -ryhmä on voinut osallistua kaikkiin suunnittelun vaiheisiin, eri ikäryhmät ja sukupuolet ovat paremmin edustettuina ja eri asioita tuodaan siten laajemmin esille (12, PPY). Toinen haastateltava kuitenkin huomautti, että myös eri ammattiryhmien edustajien, kuten käsityöläisten, kalastajien ja poronhoitajien tulisi olla tasapuolisemmin edustettuina neuvotteluissa ja Akwé: Kon -ryhmien työssä (13, PPY). 
Metsähallituksen lisäksi myös Enontekiön kunta on soveltanut Akwé: Kon -ohjeita tuulivoimarakentamista ohjaavan yleiskaavan suunnittelutyössä. Haastattelujen tekoaikana tuulivoimasuunnittelu oli tauolla, mutta haastateltavat kuvasivat kuinka Akwé: Kon -menettelyä sovellettiin suunnittelun alkuvaiheessa. Kunnan lähestymistapa Akwé: Kon -menettelyyn erosi kuitenkin Ympäristöministeriön ja Metsähallituksen lähestymistavasta. Ohjeiden suomennettu teksti kuuluu, CBD:n sihteeristön muotoilun mukaisesti:

"Vapaaehtoiset objeet sellaisten hankkeiden kulttuuristen, ympäristö- ja sosiaalisten vaikutusten arvioinnille, joita on ehdotettu toteutettavaksi alkuperäiskansa- ja paikallisybteisöjen pybillä paikoilla ja niiden perinteisesti asuttamilla tai käyttämillä maa- ja vesialueilla tai jotka todennäköissesti vaikuttavat nä̉inin.” (Ympäristöministeriö 2011)

Ympäristöministeriön linjauksen mukaan Akwé: Kon -ohjeet on Suomessa rajattu koskemaan saamelaisia. Enontekiöllä kuntasuunnittelun yhteydessä ilmaisu "alkuperäiskansayhteisöt ja paikalliset yhteisöt” ymmärrettiin kuitenkin niin, että ne käsittävät kaikki paikalliset yhteisöt $(5,6, \mathrm{EK})$. Sen mukaisesti tuulivoimasuunnittelun yhteydessä perustetut Akwé: Kon -ryhmät käsittivät paikallisia ihmisiä monista erilaisista väestöryhmistä.

\section{Paikallisen ja perinteisen tiedon sisällyttäminen maankäytön suunnitteluun}

\section{Lainsäädännölliset haasteet}

Saamelaisten informanttien mielestä saamelaisen poronhoitosysteemin ja sen erityispiirteiden ymmärtäminen on keskeinen kysymys maankäytön suunnittelussa ja hallinnassa. Kaikki saamelaiset haastateltavat nimesivät lainsäädännön puutteet suurimmaksi esteeksi sille, ettei heidän perinteistä tietoaan huomioida maankäytön suunnittelussa tai sisällytetä maankäytön suunnitelmiin. Poronhoitolaki (848/1990) on tärkein poronhoitoa ja siinä ilmenevää tietoa suojeleva lainsäädännöllinen väline. Enontekiön alueen saamelainen poronhoito pohjautuu yhä pitkälti sukujen hallitsemaan siida-järjestelmään, mutta poronhoitolaki ei kuitenkaan tunne eikä näin ollen myöskään suojaa perinteistä saamelaista poronhoidon mallia, vaan sen keskiössä ovat paliskunnat ja niiden rajat (Heinämäki ym. 2017; Olsén ym. 2017). Käsivarren erämaa-alueen hoito- ja käyttösuunnitelman kommenteissa asian tuo esille myös paikallinen Akwé: Kon -ryhmä:

"Erämaa-alueisiin liittyvässä hallinnossa ei oteta riittävästi huomioon perinteistä sïda-järjestelmää ja sukujen/perbekuntien omaa tapaa hallinnoida maata/tapaoikeutta (poronhoito, marjastus-, polttopun-, kalastus-, heinäntekopaikat). Tämä ubkaa saamelaisen kulttuurin jatkuvuntta Käsivarressa." (Metsähallitus 2017a, 116)

Erään informantin mukaan poronhoitolain puutteet heikentävät kansainvälisten sopimusten, kuten biodiversiteettisopimuksen (CBD 1992) vaikutusta:

"Kun se suomalainen poronhoito on siinä laissa nïn vahva. Se tekee sen että vaikka kummoisia näitä sopimuksia tebtäis niin ei voida noudattaa niitä. [...] Se olis byvin tärkeää kun tunnustettaisiin saamelainen poronhoito niin sitten pystyisivät käyttämään noita byväksi.” (7, PPY)

\section{Perinteisen ja paikallisen tiedon dokumentointi ja kartoitus}

Saamelaiset informantit toivoivat, että niin maankäytön suunnittelijoilla kuin suurella yleisöllä olisi enemmän tietoa saamelaisen poronhoidon erityispiirteistä. Niin ikään Akwé: Kon -ryhmän kommenteissa liittyen Käsivarren erämaan hoito- ja käyttösuunnitelmaan 
todetaan: "Muiden maankäyttäjien kuten turistien tietämättömyys saamelaiskulttuurista, kuten poronhoidosta ja saamelaisten pyhistä seitapaikoista, voi jobtaa tiedostamattakin vahingolliseen toimintaan ja olla ubka kulttuurin säilymiselle." (Metsähallitus 2017a, 116)

Metsähallituksen virkamiesten haastatteluissa tuli esiin toive paikkaan sidotun tiedon saamisesta, sillä pelkkää sanallisessa muodossa olevaa palautetta on hankala käyttää nykyisessä suunnittelujärjestelmässä.

"Paikekatieto on ehkë meidän kannalta, sunnittelun kannalta keskeistä, että saadaan ne paikat kartalle ja saadaan selvitettyä, että minkälaisia arvoja on. Paikkatieto on varmaan alueiden käytön sunnittelussa se tärkein. [...] Tämmö̈nen samaan järjestelmään integroitava paikkeatieto niin tämähän se olis sitä... se olisi suoraan byödynnettävissä sitten. Et siellä olis vaikka justïn paikallisten arvokkaaksi kokemat alueet." (1, MH)

Paikkaan sidotun tiedon tarpeen lisäksi virkamiehet toivat esiin ongelmia, joita syntyy, kun kokemusperäistä paikallista ja perinteistä tietoa sisällytetään suunnittelujärjestelmiin. Maankäytön suunnitteluprosesseissa kerätty tieto on usein muokattava, jotta se saadaan sovitettua olemassa oleviin tietokantoihin ja -järjestelmiin. Yksi informanteista kuvasi tilannetta näin:

"Meidän suunnittelujärjestelmä on kirjallinen ja se tieto mitä tuotetaan, se on suullista. On ongelmana, että niitä asioita on vaikea pukea lausunnon muotoon. [...] Tai sitten voi olla nïn että on todellakin tuotettu materiaalia älyttömän paljon, mutta se mitä sieltä oikeasti pystytään siihben meidän, suunnittelijärjestelmä nyt kun on tuommoinen tietokantapobjainen, sinne tosi bybyesti joudutaan tiivistämään [...] tietenkin ne vaikuttaa sunnitteluratkaisuibin, miten vaikka jotain sijoitetaan tai muuta, mutta sitten paljon sitä informaatiota bäviää koska sitä ei saada meidän lomakemuotoon puettua." (3, MH)

\section{Tärkeät paikat ja maisema-arvot}

Karttakyselyyn saatiin 658 vastausta, ja vastaajat merkitsivät yhteensä 1884 paikan arvoa kartoille. Eniten paikkoja merkittiin Saanan alueen sekä Kilpisjärven ja Hetan kylien ympärille (Kuva 2). Ulkopaikkakuntalaisten osuus vastauksista oli varsin suuri, ja erityisesti Enontekiön kunnassa syntyneitä oli vastaajissa vähän (16,4\%). Asuinpaikakseen Enontekiön ilmoitti $40(5 \%)$ vastaajista, ja loput vastaajat olivat joko muualla Suomessa tai rajan läheisyydessä Norjassa asuvia henkilöitä, jotka käyttävät aluetta muun muassa mökkeilyyn ja retkeilyyn. Virkistysarvot, kaunis maisema, hiljaisuus ja luonnonarvot olivat korkeimmalla sijalla vastauksissa (taulukko 1). Paikallisten ja ulkopaikkakuntalaisten vastaukset ovat monilta osin yhteneviä, mutta eroja on erityisesti luonnon monimuotoisuuden ja tuleville sukupolville tärkeiden paikkojen arvottamisessa (taulukko 1).

Huomionarvoista on, että luontaiselinkeinoihin liittyviä merkintöjä on vähän. Karttakyselyyn oli mahdollista vastata suomeksi, ruotsiksi, norjaksi tai saameksi. Saamenkielisiä vastauksia ei kyselyyn tullut ainuttakaan. On mahdotonta sanoa, miten suuri osuus kyselyyn muilla kielillä vastanneista oli saamelaisia, mutta ainakin poronhoitajien osuus vastaajista oli vähäinen. Enontekiöllä on Paliskuntain yhdistyksen mukaan 365 poronhoitajaa, mikä on noin 19 prosenttia kunnan väestöstä. Ammatikseen poronhoitajan ilmoitti kuitenkin vain 2,5 prosenttia vastaajista (kuva 3). Paikallisilta saadun palautteen perusteella nautinta-alueisiin ja kulttuuriperintöön liittyvä tieto on salaista eikä sitä haluta antaa tutkijoille. Kun Luonnonvarakeskus pyysi saamelaiskäräjiltä kommentteja sekä lausunnon karttakyselyyn, saamelaiskäräjät linjasi lausunnossaan, että nautinta-alueisiin (metsästys, kalastus, keräily) sekä kulttuuriperintöön ja pyhiin paikkoihin liittyvä tieto on paikallisten saamelaisyhteisöjen omaisuutta, jota ei voida kirjata julkisiin karttapohjiin ilman paikallisen yhteisön ennakkosuostumusta. Samalla todettiin, että se, kuka voi 


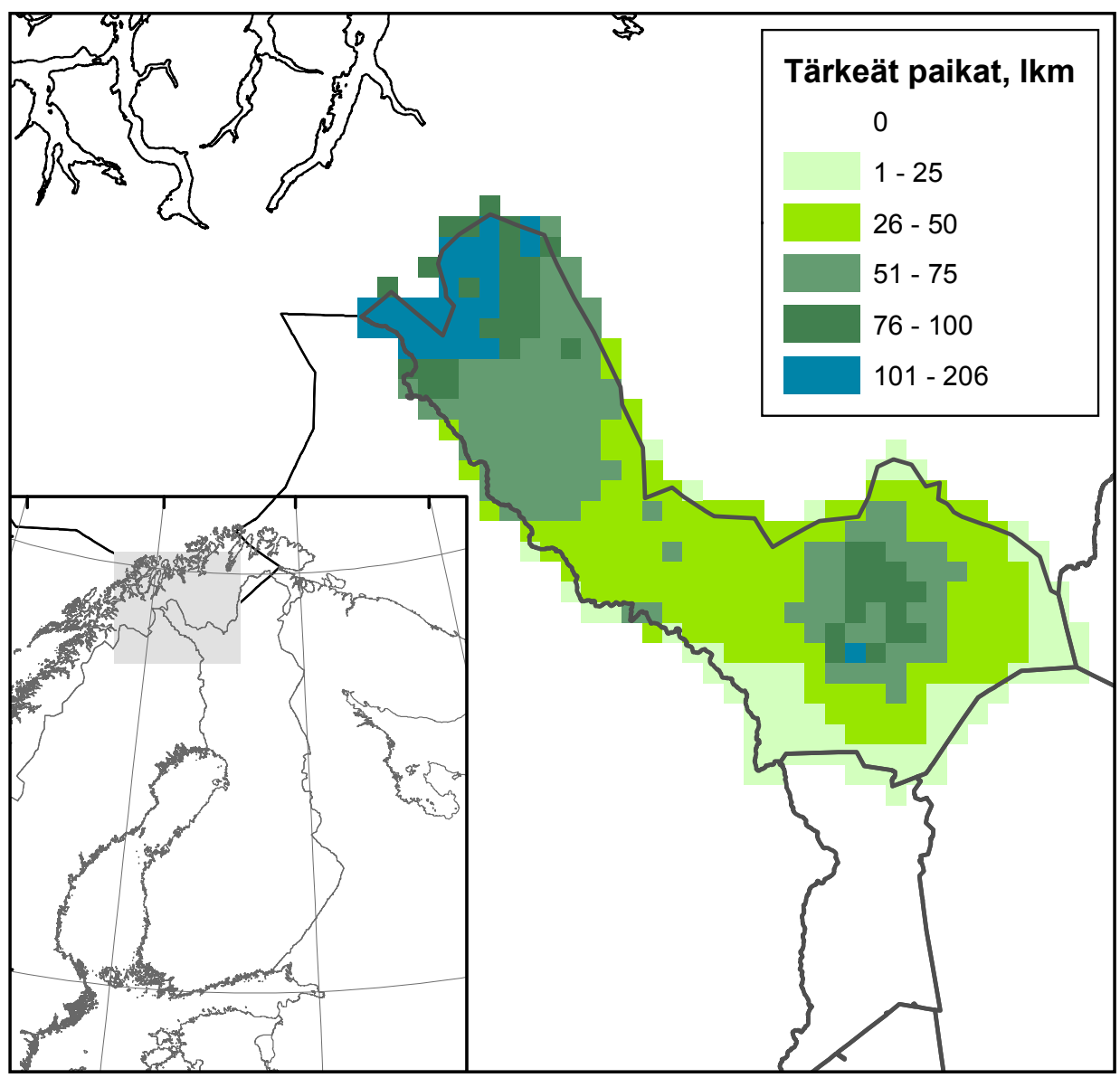

Kuva 2. Tärkeitä paikkoja kuvaavien merkintöjen summa oli suurin Saanan alueella sekä Kilpisjärven ja Hetan kylien ympärillä.

Figure 2.The sum of markings describing the important places was the highest in the region of Saana and villages of Kilpisjärvi and Hetta.

edustaa Enontekiön saamelaisyhteisöä ja antaa mahdollisen luvan tietojen keräämiseksi, on monimutkainen kysymys, jota ei ole mahdollista ratkaista projektin keston aikana. Lopulta neuvotteluissa saamelaiskäräjien kanssa sovittiin, että saamelaiskäräjien asettama työryhmä tutustuu kyselyaineistoon ennen sen julkaisua.

\section{Tulosten tarkastelu}

\section{Akwé: Kon -ohjeet, perinteinen tieto ja luonnonvarojen hallinta}

Ne informantit, jotka olivat olleet mukana Akwé: Kon -työryhmissä, pitivät menettelytavan mukanaan tuomia muutoksia positiivisina. Informanttien mukaan Akwé: Kon -menettelytavan soveltamisen myötä Metsähallituksen alueiden hoito- ja käyttösuunnittelussa huomioidaan eri näkökulmia aiempaa monipuolisemmin, ja hoito- ja käyttösuunnitelmien tietopohja ja tiedonkeruuprosessi ovat parantuneet. Ympäristöministeriö (2016) totesi Hammastunturin hoito- ja käyttösuunnitelman vahvistuskirjeessään, että Akwé: Kon -menettelytavan käyttö on tuonut tärkeää lisäarvoa hoito- ja käyttösuunittelun prosesseihin ja vuorovaikutukseen. Hammastunturin 
Taulukko I. Karttakyselyssä saatujen merkintöjen summat tärkeisiin paikkoihin liittyvistä arvoista. Table I.The sum of markings describing the values related to important places.

\begin{tabular}{|l|l|l|l|l|l|l|}
\hline & Merkintöjen summa & Yhteensä & & Sijaluku & \\
\hline Arvo & Paikalliset' $^{\prime}$ & Muut $^{2}$ & Ikm & $\%$ & Paikalliset & Muut \\
\hline Virkistys & 149 & 106 & 255 & 13.5 & I & I \\
\hline Kaunis maisema & 148 & 95 & 243 & 12.9 & 2 & 2 \\
\hline Hiljaisuus & 89 & 68 & 157 & 8.3 & 3 & 3 \\
\hline Erityinen luonnonarvo & 88 & 61 & 149 & 7.9 & 4 & 4 \\
\hline Itsessään arvokas paikka & 73 & 55 & 128 & 6.8 & 7 & 5 \\
\hline Terveys ja hyvinvointi & 80 & 48 & 128 & 6.8 & 5 & 7 \\
\hline Luonnon monimuotoisuus & 79 & 38 & 117 & 6.2 & 6 & 8 \\
\hline Tärkeys tuleville sukupolville & 59 & 51 & 110 & 5.8 & 11 & 6 \\
\hline Metsästys, kalastus, keräily & 65 & 38 & 103 & 5.5 & 9 & 8 \\
\hline Puhdas vesi & 64 & 38 & 102 & 5.4 & 10 & 8 \\
\hline Kulttuuriperintö & 72 & 29 & 101 & 5.4 & 8 & 12 \\
\hline $\begin{array}{l}\text { Paikan esittely } \\
\text { vierailijoille/turisteille }\end{array}$ & 52 & 30 & 82 & 4.4 & 12 & 11 \\
\hline Historiallinen paikka & 50 & 21 & 71 & 3.8 & 13 & 13 \\
\hline Ihmisten kohtauspaikka & 36 & 18 & 54 & 2.9 & 14 & 14 \\
\hline Mahdollisuus oppimiseen & 34 & 14 & 48 & 2.5 & 15 & 15 \\
\hline Pyhä/uskonnollinen paikka & 8 & 15 & 23 & 1.2 & 17 & 16 \\
\hline Poronhoito & 10 & 3 & 13 & 0.7 & 16 & 17 \\
\hline Yhteensä & $1156(6 I \%)$ & $728(39 \%)$ & 1884 & 100 & & \\
\hline
\end{tabular}

${ }^{1}$ Kuvan 2 osoittamalla kartta-alueella asuvat ja/ tai siellä syntyneet

${ }^{2}$ Vastaajat jotke a asuvat kartta-alueen ulkopuolella

suunnitelma oli aiemman hoito- ja käyttösuunnitelman päivitys (Metsähallitus 1996). Kun vanhaa ja uutta suunnitelmaa on verrattu, uudemman on todettu olevan moniarvoisempi ympäristöarvojen suhteen ja painottavan enemmän saamelaisia kulttuurisia arvoja (Meriläinen 2015). On myös merkkejä siitä, että Akwé: Kon -ohjeiden soveltaminen on johtanut aiempaa parempaan biokulttuuurisen monimuotoisuuden, alkuperäiskansan oikeuksien ja alkuperäiskansan elinkeinojen kulttuuristen arvojen tunnustamiseen maankäytön ja hallinnan suunnittelussa (Sarkki ym. 2018). Saamelaiskäräjät on todennut kuitenkin, että Akwé: Kon -ryhmien näkökulmia ja lausuntoja ei aina oteta huomioon tarpeeksi hyvin lopullisissa suunnitelmissa (Olsén ym. 2017). Akwé: Kon -ryhmät perustetaan joka kerta uudelleen suunnitteluprosessin käynnistyessä, ja eri ryhmille suunnatut resurssit vaihtelevat suunnitteluprosessien välillä (Olsén ym. 2017), mikä väistämättä vaikuttaa saamelaisten osallistumiseen ja siihen, minkälaista tietoa suunnitteluprosesseissa dokumentoidaan. Esimerkiksi ensimmäisessä Akwé: Kon -ryhmässä oli kahdeksan jäsentä (Juntunen \& Stolt 2013), kun taas myöhemmin yleinen jäsenten määrä on ollut viisi (esim. Metsähallitus 2017a, 2017b, 2017c).

Myös tässä tutkimuksessa erityisesti henkilöresurssien puute tuli esteeksi, kun Luonnonvarakeskus ehdotti paikkatietokyselyyn liittyvän Akwé: Kon -ryhmän perustamista edellä esitettyjen ongelmien ratkaisemiseksi.

Akwé: Kon -prosessi on joka tapauksessa luonut erillisen, pysyvän foorumin, jossa paikalliset saamelaiset voivat ilmaista näkökulmiaan ja huoliaan ja osallistua alueiden 


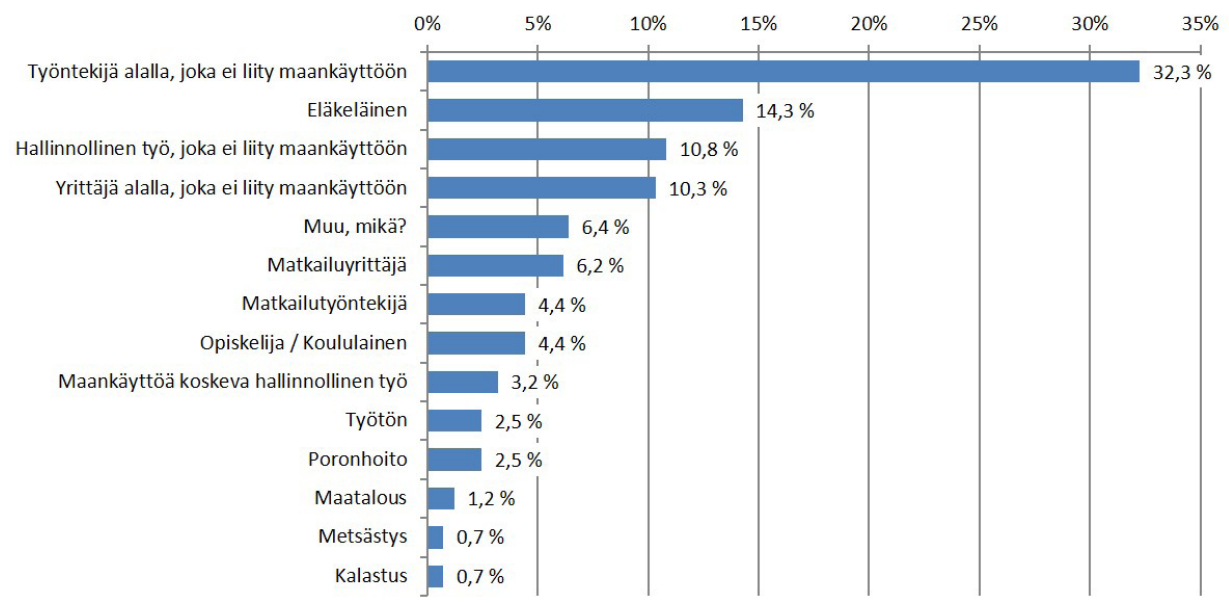

Kuva 3. Karttakyselyyn vastanneiden ammatti.

Figure 3. Profession of the respondents of the map-based survey.

suunnittelun prosesseihin koko suunnittelun ajan. Näin ollen myös suunnitelmien vaikutusten arviointiprosessi on jatkuva (Juntunen \& Stolt 2013; kts. myös Sormunen 2017). Käsivarren Akwé: Kon -ryhmä on kuitenkin tuonut esiin alueen hoito- ja käyttösuunnitelman lausuntoluonnoksessa, että

"alueeseen liittyvässä päätölesenteossa ja tiedon levittämisessä ei oteta riittävästi huomioon paliskunnan lisäksi perinteistä siida-järjestelmää ja kyläryhmillä (ja perbekunnilla) ei ole riittävää newvotteluoikentta erämaa-alueita koskevien asioiden käsittelyssä. Perinteisen siida-järjestelmän sivunttaminen ubkaa kylärybmien perinteistä tapaa ballita omia alueitaan (perinnetieto ja tapaoikeus) ja yleisesti perinteisen saamelaisen poronboidon jatkuvuntta Käsivarressa.” (Metsähallitus 2017a)

Vapaaehtoisten Akwé: Kon -ohjeiden käyttöönotolla ei voida ratkaista pitkäkestoisia, luonnonvarojen hallintaan liittyviä ongelmia. Perinteisten elinkeinojen ja perinteisen tiedon säilymisen, jatkuvuuden ja huomioimisen kannalta poronhoitolakiin (848/1990) liittyvät ongelmat ja lain mahdollinen uudistaminen ovat Akwé: Kon -ohjeita keskeisempiä kysymyksiä.

On myös huomionarvoista, että Akwé: Kon -ohjeita ei tällä hetkellä sovelleta laajemmin alueellisessa luonnonvarojen ja kuntatason suunnittelussa, eikä ympäristövaikutusten arvioinneissa, ja siten menetelmän vaikutukset ovat paikallisia koskien lähinnä Metsähallituksen hallinnoimia erämaa-alueita ja muita suojelualueita saamelaisalueella. Ainoastaan Enontekiön kunta on soveltanut Akwé: Kon -ohjeita tuulivoimarakentamista ohjaavan yleiskaavan suunnittelutyössä. Kunnan linjauksessa Akwé: Kon -menettelytavan ei katsottu koskevan erityisesti saamelaisten oikeuksia alkuperäiskansana, vaan kaikkia paikallisyhteisöjä. Tällä tavalla toteutettuna menettely ei juurikaan eroa tavallisesta sidosryhmien kuulemisesta, joihin ottavat osaa erilaiset paikalliset yhteisöt, ryhmät ja yhdistykset.

\section{Perinteinen tieto maankäytön suunnittelussa: haasteet ja tiedon yhteistuottaminen}

Tutkimuksemme perusteella paikallisen kokemusperäisen ja perinteisen tiedon sisällyttämiseen osaksi maankäytön suunnitteluprosesseja liittyy edelleen haasteita. Erityisesti Metsähallituksen suunnittelijoiden haastatteluista kävi ilmi, että perinteisen ja paikallisen tiedon tarkka paikantaminen ja dokumentointi parantaisivat tiedon 
käyttöä osana suunnittelua. Osallistavat paikkatietomenetelmät voivat tarjota toimivan työkalun perinteisen tiedon dokumentointiin ja erilaisten ympäristöön liittyvien arvojen paikallistamiseen (esim. Alessa ym. 2008; Barlindhaug 2013).

Saamelaisessa kontekstissa aloitteen tiedon keruuseen tulisi kuitenkin lähteä yhteisön sisältä, sillä saamelaiseen kulttuuriperintöön ja nautinta-alueisiin liittyy sellaisia ratkaisemattomia kysymyksiä, jotka tekevät tiedon keräämisen kartoille vaikeaksi. Saamelaiskäräjien linjauksen mukaan saamelainen perinteinen tieto on paikallisen yhteisön omaisuutta, eikä tutkijoilla siksi ole oikeutta kerätä sitä kartoille tai esittää laajemmalle yleisölle ilman kyseessä olevan yhteisön kirjallista suostumusta (Saamelaiskäräjien lausunto Luonnonvarakeskukselle).

Perinteisellä tiedolla ei ole lakiin perustuvaa tekijänoikeussuojaa, mutta esimerkiksi Yhdistyneiden kansakuntien julistus alkuperäiskansojen oikeuksista (UNDRIP 2007) sekä Biologista monimuotoisuutta koskeva yleissopimus (CBD 1992) suojaavat alkuperäiskansojen perinteistä tietoa. Myös Suomen perustuslaki (731/1999) takaa saamelaisille oikeuden kehittää ja ylläpitää omaa kulttuuriperintöään.

Saamelaisten oikeus perinteiseen tietoonsa nousi vahvasti esiin Enontekiön karttakyselyn yhteydessä. Luonnonvarakeskuksen ja saamelaiskäräjien välisissä neuvotteluissa sovittiin, että saamelaiskäräjillä ja paikallisyhteisöillä on mahdollisuus tutustua paikannettuun aineistoon ja antaa siitä lausuntonsa. Lopulta karttakyselyyn ei tullut yhtään saamenkielistä vastausta ja saadussa aineistossa luontaiselinkeinojen ja kulttuuriperinnön merkitys näyttäytyy vähäisenä. Poronhoito, joka on Enontekiöllä merkittävä elinkeino sekä kulttuurisesti että taloudellisesti, jää aineistossa lähes näkymättömäksi. Samaan aikaan tutkimusta varten haastatellut saamelaiset kuitenkin toivoivat, että suunnittelijoilla ja myös suurella yleisöllä olisi enemmän tietoa saamelaisesta poronhoidosta. Edellä kuvatun kaltaisen ristiriidan ratkaisemiseksi tarvitaan uudenlaisia toimintatapoja. Paikkatietokyselystä saamiemme kokemusten ja siitä käydyn keskustelun perusteella Akwé: Kon -menettelytapa osoittautui kuitenkin liian vaikeaksi toteuttaa henkilöresurssien vähyydestä johtuen. Tutkimusprojekteja varten tarvittaisiin vastaava, mutta kevyempi menettelytapa.

Ruotsin saamelaisalueella on saatu hyviä tuloksia tiedon yhteistuottamisen (knowledge co-production) ja paikkatietomenetelmien yhdistämisestä hankkeessa, jossa kehitettiin paikkatietoa hyödyntävä menetelmä yhteistyössä poronhoitajien kanssa (Sandström 2015; Sandström ym. 2012). Tiedon yhteistuottaminen tarkoittaa vastavuoroista tiedon keräämisen tapaa, jossa maankäyttöön liittyvistä asioista vastaavat virkamiehet, tutkijat ja paikallinen yhteisö tuottavat tietoa yhdessä sekä sopivat tiedon käytöstä ja tallentamisesta (Tengö ym. 2014). Tiedon yhteistuottaminen on tärkeä osa resurssien yhteishallintaa erityisesti arktisessa Kanadassa (Armitage ym. 2011; Berkes 2012). Berkes (2009) on kuvannut resurssien yhteishallintaa ja tiedon yhteistuottamista tietokumppanuudeksi (a knowledge partnership) ja ongelmanratkaisuprosessiksi, johon kuuluvat neuvottelu, asioiden pohtiminen, tiedon tuottaminen ja yhteinen oppiminen. Akateemisessa tutkimuksessa puhutaan yhteisölähtöisestä lähestymistavasta, joka on niin ikään tiedon yhteistuottamisen tapa. Yhteisölähtöistä tutkimustapaa pidetään sopivana erityisesti alkuperäiskansatutkimuksessa, osittain siitä syystä, että valtakulttuurista tulevilla tutkijoilla ja alkuperäiskansayhteisöillä on erilainen etnohistoria, minkä vuoksi käsitykset esimerkiksi ympäristöstä, maankäyttötavoista, luontosuhteesta ja identiteetistä eroavat toisistaan (Olsén ym. 2017). Tavoitteena myös yhteisölähtöisessä tutkimustavassa on, että tutkijat ja tutkimukseen osallistuvat henkilöt tekevät tutkimusta ja tuottavat tietoa yhdessä. Kun paikalliset yhteisöt ja alkuperäiskansat ovat mukana tutkimuksen teossa tutkimuskysymysten laadinnasta lähtien, heillä on mahdollisuus vaikuttaa tutkimusprosessiin, jolloin myös tutkimustulokset vastaavat alkuperäiskansojen arvoja ja todellisuutta paremmin (Pontes Ferraida \& Gendrom 2011, 157; Olsén ym. 2017).

Ruotsin saamelaisalueella yhdessä poronhoitajien kanssa kehitetty RenGIS-karttatyökalu toimii esimerkkinä siitä, että parhaimmillaan paikkatietomenetelmät voivat tarjota 
poronhoitajille välineen tuoda perinteistä tietoaan osaksi maankäytön suunnittelua (Sandström 2015). Karttatyökalun avulla on mahdollista osoittaa tarkasti poronhoidolle tärkeät alueet, ja auttaa näin yhteismitallistamaan tietoa maankäyttöneuvotteluissa. Kyseessä oli kuitenkin hyvin eri tarkoitukseen tehty osallistavan paikkatiedon kerääminen kuin Enontekiön paikkatietokyselyssä, jossa haluttiin kartoittaa mahdollisimman laajasti eri ryhmien näkemyksiä maankäytöstä. Yhden varsin rajatun yhteisön kanssa toteutettu yhteisölähtöinen paikkatietojen kerääminen jättää kuitenkin ulkopuolelle aluetta käyttävät ei-paikalliset ihmiset. BuSK-projektissa toteutetun karttakyselyn tavoitteena oli saada alueen maankäytöstä kokonaiskuva, jossa eri käyttäjäryhmät olivat edustettuina, ja tällaisessa tapauksessa yhteisölähtöisen menetelmän käyttäminen on haasteellista. Tiedon yhteistuottaminen voi parantaa paikkatietoaineistojen edustavuutta erityisesti kerätyn tiedon suhteen. Mutta mikäli maankäytöstä halutaan saada kokonaiskuva, on osallistettava laajasti kaikkia alueiden käyttäjiä.

Metsähallituksessa työskentelevät informantit toivat haastatteluissa esiin suunnittelujärjestelmien ja perinteisen tiedon yhteensopimattomuuden: kun luonteeltaan narratiivinen tieto muokataan lomakemuotoon tai laskentataulukoihin sopivaksi, informaatiota katoaa. Lisäksi perinteinen tieto on kontekstisidonnaista, eli se on sidoksissa tiettyyn paikkaan, elinkeinoon, kulttuuriseen käytänteeseen tai tapahtumaan (Berkes 2012). Alkuperäiskansojen näkökulmasta tieto voi muuttua merkityksettömäksi, jos sen alkuperäinen asiayhteys katoaa. Toisaalta perinteistä tietoa katoaa koko ajan muun muassa elinkeinojen muutosten, kielten ja luonnonympäristöjen katoamisen vuoksi, ja siksi, että tieto ei enää siirry sukupolvelta toiselle (Markkula \& Helander 2014). Parhaimmassa tapauksessa suunnittelujärjestelmiin ja karttamenetelmiä käyttäen voidaan tallettaa arvokasta perinteistä tietoa, mutta tämä vaatii onnistuakseen kiinteää yhteistyötä alkuperäiskansojen ja paikallisten yhteisöjen kanssa.

\section{Osallistavat paikkatietomenetelmät ja biokulttuurinen monimuotoisuus}

Biokulttuurinen monimuotoisuus pitää sisällään niin biologisen kuin kulttuurisenkin diversiteetin. Niin CBD -sopimuksen artikla 8(j) kuin sen alainen Akwé: Kon -menettelytapa pyrkivät huomioimaan alkuperäiskansojen kulttuurien ja luonnon kiinteän yhteyden. Luontaiselinkeinoja harjoittaville ja kiinteässä luontosuhteessa eläville luonto näyttäytyy myös kulttuurimaisemana: luonnonpaikkoihin liittyy lukuisia kulttuurisia ja pyhï̈ merkityksiä. Paikkatietomenetelmät voisivat olla hyvä työkalu biokulttuurisen monimuotoisuuden dokumentoimiseen, sillä alkuperäiskansoille ja paikallisille ihmisille tärkeisiin paikkoihin liittyy monia rinnakkaisia ja limittäisiä arvoja: esimerkiksi luontoarvoja, virkistysarvoja, paikan käyttöön liittyviä arvoja (metsästys/kalastus/poronhoito) ja kulttuurisia arvoja (mm. pyhät paikat). Mutta kuinka hyvin karttamenetelmät voivat välittää tätä paikkoihin liittyvää biokulttuurista monimuotoisuutta? Tutkimuksemme mukaan kulttuurinen ja elinkeinoihin liittyvä tieto on usein salattua, eikä sen kerääminen kartoille ole kaikissa tapauksissa mahdollista. Enontekiöllä tehdyssä karttakyselyssä luontaiselinkeinoihin liittyviä karttamerkintöjä on niukasti. Poronhoito, joka on tärkeä elinkeino alueen saamelaisille ja jolla on suuri kulttuurinen merkitys, näyttäytyy vastauksissa vähämerkityksisenä. Näin ollen voidaan todeta, että Enontekiöllä toteutettu karttakysely ei tavoittanut alueen biokulttuurista monimuotoisuutta sen todellisessa laajuudessa. Virkistys- ja maisema-arvot korostuivat vastauksissa, ja tärkeiksi arvoiksi nousivat myös hiljaisuus ja erityiset luontoarvot. Lisäksi karttakysely toi esiin joitakin kiinnostavia eroja paikallisten ja ei-paikallisten ihmisten vastauksissa. Paikallisten ihmisten vastauksissa luonnon monimuotoisuus on korkeammalla sijalla kuin ulkopaikkakuntalaisten vastauksissa. Ulkopaikkakuntalaisten vastauksissa paikkojen merkitys tuleville sukupolville on korkeammalla sijalla, mikä voi kertoa erityisesti Kilpisjärven alueen ylisukupolvisesta merkityksestä retkeilypaikkana muualla Suomessa asuville ihmisille. 
Paikkatietomenetelmien avulla voidaan tuoda hyvin esiin niitä erilaisia merkityksiä ja intressejä, joita eri ihmisryhmiin kuuluvilla paikkoihin liittyen on. Merkitysten ja intressien ristiriidoista syntyvät usein myös maankäyttöön liittyvät konfliktit (esim. Nikula ym. 2020). Haasteena paikkakyselyissä on kuitenkin se, miten saada erilaiset ryhmät kattavasti edustetuiksi.

\section{Johtopäätökset}

Tutkimuksemme toi ilmi kokemusperäisen paikallistiedon ja erityisesti perinteisen tiedon dokumentointiin ja paikantamiseen liittyviä ristiriitoja saamelaisalueella. Kulttuuriperintöön, pyhiin paikkoihin ja nautinta-alueisiin (metsästys, kalastus, keräily) liittyvä tieto on saamelaiskäräjien linjauksen mukaan paikallisten saamelaisten omaisuutta, jonka kirjaamiseksi julkisiin karttapohjiin tarvitaan paikallisen yhteisön ennakkosuostumus. Ennakkosuostumuksen saamisen esteeksi muodostui kuitenkin paikallisen saamelaisyhteisön määrittämisen vaikeus. Kysymystä siitä, kuka voi edustaa Enontekiön saamelaisyhteisöä ja antaa mahdollisen luvan tietojen keräämiseksi, ei ollut projektin keston aikana mahdollista ratkaista.

Paikkatietomenetelmät voivat parhaimmillaan olla hyvä työkalu paikallisen ja perinteisen tiedon keräämiseen sekä biokulttuurisen monimuotoisuuden ja paikkoihin liittyvien arvojen ja intressien kartoittamiseen. Haasteena paikkakyselyissä on kuitenkin se, miten saada erilaiset ryhmät kattavasti edustetuiksi. Lisäksi erityisesti perinteisen tiedon dokumentointiin liittyy monia haasteita, jotka juontuvat lainsäädännön puutteista ( $\mathrm{mm}$. poronhoitolaki), narratiivisen tiedon ja suunnittelujärjestelmien yhteensopimattomuudesta sekä siitä, että osa tiedosta on salaista tai sensitiivistä, eikä sitä haluta jakaa ulkopuolisten kanssa. Tutkimukseen osallistuneet saamelaiset informantit kuitenkin toivoivat, että suunnittelijoilla ja myös suurella yleisöllä olisi enemmän tietoa saamelaisesta kulttuurista ja poronhoidosta, ja Metsähallituksen suunnittelijat toivat esiin paikkaan sidotun paikallistiedon tarpeen suunnittelutyössä. Tämän ristiriidan ratkaisemiseksi tarvitaan erityisiä menettelytapoja. Yksi näistä on Akwé:Kon -menettelytapa, joka tarjoaa saamelaisten yhteisöjen osallistamiseen hyvän työkalun, joka tuo paikalliset saamelaiset osaksi maankäytön suunnittelua aiempaa tasavertaisempina osapuolina. Paikkatietokyselystä saadun kokemuksemme perusteella Akwé:Kon -menettelytapa on tutkimusprojektien tarpeisiin nähden kuitenkin liian paljon henkilöresursseja vaativa. Yhteisölähtöinen paikkatietojen keruu sekä tiedon yhteistuottaminen ovat hyviä keinoja paikallisten osallistamiseen ja voivat parantaa paikkatietokyselyn edustavuutta. Niiden lisäksi tarvitaan kuitenkin myös alueen muiden asukkaiden ja käyttäjien näkemyksiä silloin, kun tietyn alueen maankäytöstä halutaan saada kokonaiskuva.

Saamelaisten näkökulmasta ensisijaisen tärkeää olisi poronhoitolain kehittäminen niin, että saamelaisen poronhoidon erityispiirteet, erityisesti siida-järjestelmä, tulisivat huomioiduiksi. Kansallisella tasolla lainsäädännön kehittäminen ja paikallisella tasolla Akwé:Kon -menettelytavan ja yhteisölähtöisen paikkatietojen keruun kehittäminen voisivat edesauttaa perinteisen ja paikallisen tiedon parempaa dokumentointia ja johtaa biokulttuurisen monimuotoisuuden paremmin huomioivaan maankäyttöön Suomen saamelaisalueella.

\section{Kiitokset}

Kiitos kartoista Vesa Nivalalle, Risto Viitaselle ja Arto Vitikalle. Kiitos Sini Kantolalle, jonka tekemää haastattelua on käytetty osana tutkimusta. Tutkimus on tehty osana Building Shared Knowledge Capital to Support Natural Resource Governance (BuSK) -projektia, jonka on rahoittanut EU:n Pohjoinen periferia ja Arktinen -ohjelma. 


\section{Lähteet}

Alessa, A., A. Kliskey \& Brown, G. (2008) Social-ecological hotspots mapping: A spatial approach for identifying coupled social-ecological space. Landscape and Urban Planning 85(1) 27-39. https://www. sciencedirect.com/science/article/pii/S0169204607002216

Armitage, D., F. Berkes, A. Dale, E. Kocho-Schellenberg \& Patton, E. (2011) Co-management and the coproduction of knowledge: Learning to adapt in Canada's Arctic. Global Environmental Change 21(3) 995-1004. https://www.sciencedirect.com/science/article/abs/pii/S0959378011000665

Barlindhaug, S. (2013) Cultural Sites, Traditional Knowledge and Participatory Mapping. Long-Term Land Use in a Sámi community in coastal Norway. V Doctoral thesis, Universitet i Tromsø, Norway.

https://munin.uit.no/bitstream/handle/10037/5405/thesis.pdf? sequence=2

Berkes, F. (1993) Traditional Ecological Knowledge in Practice. Teoksessa Inglis, J. (toim.) Traditional Ecological Knowledge; Concepts and Cases. Canadian Museum of Nature and the International Development Research Centre, Ottawa, 1-9.

Berkes, F. (2009) Evolution of co-management: Role of knowledge generation, bridging organizations and social learning. Journal of Environmental Management 90(5) 1692-1702. https://www.sciencedirect.com/ science/article/pii/S0301479708003587

Berkes, F. (2012) Sacred Ecology, $3^{\text {rd }}$ edition. Taylor \& Francis, Philadelphia.

Brown, G. \& Kyttä, M. (2014) Key issues and research priorities for public participation GIS (PPGIS): A synthesis based on empirical research. Applied Geograpby 46 122-136. https://doi.org/10.1016/j. apgeog.2013.11.004

Chen, W.C. \& Gilmore, M. (2015) Biocultural Rights: A New Paradigm for Protecting Natural and Cultural Resources of Indigenous Communities. The International Indigenous Policy Journal 6(3). https://ir.lib.uwo. $\mathrm{ca} /$ iipj/vol6/iss $3 / 3$

CBD (1992) Biologista monimuotoisuutta koskeva yleissopimus. https://www.un.org/en/events/ biodiversityday/convention.shtml

Danielsen, F., N.D. Burgess, A. Balmford, P.F. Donald, M. Funder, J.P. Jones, D. Balete ym. (2009) Local Participation in Natural Resource Monitoring: a Characterization of Approaches. Conservation Biology 23(1) 31-42. https://doi.org/10.1111/j.1523-1739.2008.01063.x

Danielsen, F., Jensen, P. M., Burgess, N. D., Coronado, I., Holt, S., Poulsen, M. K., Rueda, R. M. ym. (2014) Testing Focus Groups as a Tool for Connecting Indigenous and Local Knowledge on Abundance of Natural resources with Science-Based Land Management Systems. Conservation Letters 7 380-389. https:// doi.org/10.1111/conl.12100

Erämaalaki (1991/62). https://www.finlex.fi/fi/laki/ajantasa/1991/19910062

Forbes, B.C., M. Bölter, L. Müller-Wille, J. Hukkinen, F. Müller, F., N. Gunslay, \& Konstantinov, Y. (toim.) (2006) Reindeer management in northernmost Europe: linking practical and scientific knowledge in social-ecological systems. Ecological Studies 184. Springer, Berlin.

Gadamus, L. \& Raymond-Yakoubian, J. (2015) Qualitative Participatory Mapping of Seal and Walrus Harvest and Habitat Areas: Documenting Indigenous Knowledge, Preserving Local Values, and Discouraging Map Misuse. International Journal of Applied Geospatial Research 6 76-93.

Heikkonen, A. (2014) Ylimuonion valtionmaiden käyttösuunitelma. Metsähallituksen metsätalouden julkaisuja 70, Vantaa. https://julkaisut.metsa.fi/assets/pdf/mt/mt70.pdf

Heinämäki, L., Valkonen, S., Olsén, L., Allard, C. Kircher, S. \& Xanthaki, A. (2017) Saamelaisten oikeuksien toteutuminen: kansainvälinen oikeusvertaileva tutkimus. Valtioneuvoston selvitys- ja tutkimustoiminnan julkaisusarja 4, Helsinki.

Jokinen, M., Sarkki, S. \& Heikkinen, H.I. (2016) The well-being effects of localized multi-level environmental governance: case of Kilpisjärvi. Nordia Geographical Publications Yearbook 2016: Geographies of WellBeing in the North 45(2) 19-36.

Juntunen, S. \& Stolt, E. (2013) Akwé: Kon objeiden soveltaminen Hammastunturin erämaa-alueen hoito- ja käyttösuunnitelmassa. Metsähallituksen luontopalvelut. https://www.cbd.int/doc/world/fi/fi-nr-oth-en.pdf

Kahila-Tani, M., Broberg, A., Kyttä, M. \& Tyger, T. (2016) Let the Citizens Map-Public Participation GIS as a Planning Support System in the Helsinki Master Plan Process. Planning practice \& Research 31(2) 195-214. https://doi.org/10.1080/02697459.2015.1104203

Kahila, M. \& Kyttä, M. (2009) SoftGIS as a Bridge-Builder in Collaborative Urban Planning. Teoksessa Geertman S. \& Stillwell, J. (toim.) Planning Support Systems Best Practice and New Methods. The GeoJournal Library 95. Springer, Dordrecht.

Kantola, S., Uusitalo, M., Nivala, V. \& 'Tuulentie, S. (2018) Tourism resort users' participation in planning: Testing the public participation geographic information system method in Levi, Finnish Lapland. Tourism Management Perspectives 27 22-32. https://doi.org/10.1016/j.tmp.2018.04.001 
Kivinen, S., Vartiainen, K. \& Kumpula T. (2018) People and Post-Mining Environments: PPGIS Mapping of Landscape Values, Knowledge Needs, and Future Perspectives in Northern Finland. Land 7(4) 151. https:// doi.org/10.3390/land7040151

Lapin yliopisto (2009) Hyvä tieteellinen käytäntö. Lapin yliopiston tutkimuseettiset toimintaohjeet. https:/ / www.ulapland.fi/loader.aspx?id=072e1fb7-a53a-4ab5-b3d2-8068b95df7e4

Maankäyttö- ja rakennuslaki (1999/132). https://www.finlex.fi/fi/laki/ajantasa/1999/19990132

Markkula, I. \& Helander-Renvall, E. (2014) Ekologisen Perinnetiedon Käsikirja. Lapin yliopistopaino, Rovaniemi. http://urn.fi/URN:ISBN:978-952-484-798-8

Metsähallitus (1996) Hammastunturin erämaan boito-ja käyttösunnitelma. Metsähallituksen luonnonsuojelujulkaisuja B 32, Vantaa. https://julkaisut.metsa.fi/assets/pdf/lp/Bsarja/b32.pdf

Metsähallitus (2016) Hammastunturin erämaa-alueen hoito- ja käyttösuunnitelma. Metsähallituksen luonnonsuojelujulkaisuja C 124, Vantaa. https://julkaisut.metsa.fi/assets/pdf/lp/Csarja/c142.pdf

Metsähallitus (2017a) Käsivarren erämaa-alueen hoito- ja käyttösuunnitelma. Lausunnolle lähetetty versio. http:// www.metsa.fi/documents/10739/1110148/kasivarren_hks_lausunnolle.pdf/d9b8616e-e462-41a2-b8b2$55 \mathrm{~b} 27 \mathrm{bb} 9 \mathrm{c} 67 \mathrm{f}$

Metsähallitus (2017b) Saanan alueen hoito-ja käyttösunnitelma. Lausunnolle lähetetty versio. http:/ / wmw. metsa.fi/ documents/10739/1110148/saana_hks_ybteenveto.pdf/9db5ffa2-5885-4fc4-8d2f-2da0424fa94e

Metsähallitus (2017c) Kevon luonnonpuiston ja Natura 2000 -alueen hoito- ja käyttösuunnitelma. Metsähallituksen luonnonsuojelujulkaisuja C 149, Vantaa. https://julkaisut.metsa.fi/assets/pdf/lp/Csarja/c145.pdf

Metsähallitus (2018) Puljun erämaan Natura-alueen hoito- ja käyttösuunnitelma. Metsähallituksen luonnonsuojelujulkaisuja C 162, Vantaa. https://julkaisut.metsa.fi/assets/pdf/lp/Csarja/c162.pdf

Nikula, A., Turunen, M. Bogadottir, R., Markkula I. \& Kantola, S. (2020) PPGIS for a better understanding of people's values - experiences from Finland and the Faroe Islands. Teoksessa McDonagh, J. \& Tuulentie, S. (toim.) Sharing Knowledge for Land Use Management: Decision-making and Expertise in Europe's Northern Periphery (painossa).

Olsén, S., A. Harkoma, L. Heinämäki, \& Heiskanen, H. (2017) Saamelaisten perinnetiedon buomioiminen ympäristöpäätöksenteossa. Juridica Lapponica 41. Lapin yliopistopaino, Rovaniemi. http://urn.fi/ URN:ISBN:978-952-484-989-0

Pietilä, M. \& Fagerholm, N. (2018) A management perspective to using Public Participation GIS in planning for visitor use in national parks. Journal of Environmental Planning and Management 62(7) 1133-1148. https:// doi.org/10.1080/09640568.2018.1473757

Pontes Ferraida, M. \& Gendron, F. (2011) Community-based participatory research with traditional and indigenous communities of the Americas: History contex and future directions. International Journal of Critical Pedagogy 3(3) 153-168.

Poronhoitolaki (848/1990) https://www.finlex.fi/fi/laki/ajantasa/1990/19900848

Sandström, P. (2015) A toolbox for co-production of knowledge and improved land use dialogues - the perspective of reindeer busbandry. Doctoral thesis, Swedish University of Agricultural Sciences, Umeå, Sweden. https://pub. epsilon.slu.se/11881/

Sandström, P., C. Sandström, J. Svensson, L. Jougda, \& Baer, K. (2012) Participatory GIS to mitigate reindeer husbandry and forestry land use conflicts in Vilhelmina Model Forest, Sweden. The Forest Chronicle 88 254-260.

Sarkki, S., H.I. Heikkinen, V-P. Herva \& Saarinen, J. (2018) Myths on local use of natural resources and social equity of land use governance: Reindeer herding in Finland. Land Use Policy 77 322-331. https://doi. org/10.1016/j.landusepol.2018.05.055

Sormunen, J. (2017) Yhteishallintaa Hammastunturilla? Akwé: Kon -objeiden vaikutus Hammastunturin erämaa-alueen ballintaan. Pro gradu- tutkielma, Turun yliopisto.

Suomen perustuslaki (731/1999). https://www.finlex.fi/fi/laki/ajantasa/1999/19990731

Tengö, M., M. Malmer, E. Brondizio, T. Elmqvist, \& Spierenburg, M. (2014) Connecting Diverse Knowledge Systems for Enhanced Ecosystem Governance: The Multiple Evidence Base Approach. Ambio 43(5) 579-591. https://doi.org/10.1007/s13280-014-0501-3

Tolvanen, A. Kangas, K, Vendelin, I., Huhta, E. Hytönen, M., Jäkäläniemi, A., Kyttä, M. Nikula, A., Nivala, V., Tarvainen, O., Tuulentie, S. \& Tyrväinen, L. (2014). Vaaka punnitsee, arvottaa, tasapainottaa -toimintamalli Vaara-Kainuun matkailualueiden suunnitteluun. http://urn.fi/URN:ISBN:978-951-40-2483-2

Tuomi, J. \& Sarajärvi, A. (2009) Laadullinen tutkimus ja sisällönanalyysi. Gummerus, Jyväskylä.

Tuulentie, S. (2017) Destination development in the middle of the Sápmi: whose voice is heard and how? Teoksessa Viken, A. \& Müller, D. (toim.) Arctic Indigenous Tourism. Tourism and Cultural Change 51. Channel View Publications, 122-136. http://jukuri.luke.fi/handle/10024/540275

UNDRIP (2007) YK:n julistus alkuperäiskansojen oikeuksista. <https://www.un.org/development/desa/ indigenouspeoples/declaration-on-the-rights-of-indigenous-peoples.html>. 3.12.2020.

Veland, S., Lynch, A., Bichoff $\square$ Mattson, Z., Joachim, L., \& Johnson, N. (2014) All strings attached: Negotiating 
relationships of geographic information science. Geographical Research 52(3) 296-308. https://doi. org/10.1111/1745-5871.12070

Yli-Pelkonen, V. \& Kohl, J. (2005) The role of local ecological knowledge in sustainable urban planning: perspectives from Finland. Sustainability: Science, Practice and Policy 1(1) 3-14. https://doi.org/10.1080/15 487733.2005.11907960

Ympäristöministeriö (2011) Akwé: Kon -objeet. Ympäristöhallinnon ohjeita 1/2011. http://julkaisut. valtioneuvosto.fi/handle/10138/41525 